\title{
SINTESA UNSUR-UNSUR SPIRITUALITAS, BUDAYA, DAN KEARIFAN LOKAL MASYARAKAT BALI DALAM MATERI KULIAH AKUNTANSI SOSIAL DAN LINGKUNGAN
}

\author{
Oleh: \\ Putu Sukma Kurniawan \\ Jurusan Akuntansi Program S1 Universitas Pendidikan Ganesha \\ putusukma1989@gmail.com
}

\begin{abstract}
Abstrak
Pendidikan dan pengajaran akuntansi bertujuan untuk menghasilkan lulusan yang nantinya akan bekerja pada profesi akuntansi. Diharapkan nantinya lulusan yang dihasilkan tidak hanya memiliki kemampuan teknis dan profesional yang baik, tetapi juga memiliki kepribadian dan karakter yang baik. Kualitas pendidikan dan pengajaran akuntansi akan menentukan kualitas lulusan yang dihasilkan. Memasukkan unsur-unsur spiritualitas, budaya, dan kearifan lokal seperti konsep tri hita karana, catur purusa artha, manyama braya, paras paros, dan sagilig sagulug salunglung sabyantaka dalam pendidikan dan pengajaran akuntansi khususnya dalam mata kuliah akuntansi sosial dan lingkungan diharapkan dapat membantu untuk menghasilkan lulusan akuntansi yang memiliki kepribadian dan karakter yang baik.
\end{abstract}

Kata kunci: spiritualitas, budaya, kearifan lokal, akuntansi sosial dan lingkungan

\begin{abstract}
Accounting education aims to produce graduates who will be working on the accounting profession. Expected later graduates produced not only have the technical ability and a good professional, but also have a good personality and good character. The quality of accounting education will determine the quality of graduates produced. Incorporating elements of spirituality, culture and local wisdom likes tri hita karana, catur purusa artha, manyama braya, paras paros, and sagilig sagulug salunglung sabyantaka concepts in accounting education especially in social and environmental accounting can help to produce accounting graduates who have good personality and good character.
\end{abstract}

Keywords: spirituality, culture, local wisdom, social and environmental accounting

\section{PENDAHULUAN}

Akuntansi saat ini telah memasuki dimensi internasional. Internasionalisasi dalam akuntansi terjadi karena dunia bisnis dan ekonomi yang semakin global. Tidak dapat dipungkiri bahwa ketika semua dimensi dunia bisnis dan ekonomi mengglobal, akuntansi pun ikut masuk dalam dimensi internasional. Hal ini dikarenakan akuntansi adalah bagian dari dunia bisnis dan ekonomi. Konsep baru dalam ilmu akuntansi yang muncul akibat globalisasi dan perkembangan dunia bisnis yang semakin cepat adalah munculnya konsep akuntansi sosial dan lingkungan (social and environmental accounting). Akuntansi sosial dan lingkungan merupakan perubahan paradigma dari akuntansi konvensional. Akuntansi sosial dan lingkungan memasukkan dimensi sosial dan lingkungan ke dalam pencatatan akuntansi. Hasil akhirnya adalah akuntansi sosial dan lingkungan berpusat tidak hanya pada indikator ekonomi yang dicapai perusahaan, tetapi juga memikirkan dampak sosial dan lingkungan yang ditimbulkan dari kegiatan 
perusahaan. Adanya globalisasi dalam akuntansi tidak hanya menyebabkan perkembangan yang baru dalam konsepkonsep ilmu akuntansi tetapi juga menimbulkan perubahan dalam dimensi pendidikan dan pengajaran akuntansi, khususnya di tingkat perguruan tinggi.

Konsep pendidikan dan pengajaran akuntansi saat ini telah berkembang dengan cepat. Materi pendidikan dan pengajaran akuntansi saat ini merujuk pada materi pendidikan akuntansi pada universitasuniversitas ternama di luar negeri, khususnya dari Amerika Serikat. Akibatnya akuntansi Amerikalah yang berkembang sampai munculnya ide penyeragaman praktek akuntansi internasional (Sylvia, 2014). Materi perkuliahan, rujukan referensi, dan tata cara perkuliahan lebih menjadi bersifat internasional. Dampak dari adanya hal ini adalah pendidikan dan pengajaran akuntansi akan disampaikan dengan cara yang tidak sesuai dengan kondisi mahasiswa. Artinya ketika materi perkuliahan, rujukan referensi, dan tata cara perkuliahan disampaikan dengan praktek atau cara yang tidak sesuai dengan kondisi lingkungan mahasiswa, maka materi perkuliahan akan sulit diterima oleh mahasiswa. Terlebih lagi istilah-istilah dalam akuntansi kini lebih banyak menggunakan Bahasa Inggris dalam buku teks asli sehingga mahasiswa cukup sulit memahami hal tersebut. Sylvia (2014) dalam tulisannya secara khusus menyampaikan bahwa penggunaan istilah Bahasa Inggris dalam akuntansi dapat menimbulkan perbedaan penafsiran antara akademisi dengan praktisi. Hal ini sejalan dengan pendapat Mulawarman (2008) yang berpendapat bahwa sistem pendidikan akuntansi yang saat ini berkembang di Indonesia telah lepas dari realitas masyarakat Indonesia karena sistem pendidikan akuntansi yang sekarang diadopsi langsung dari luar negeri tanpa disesuaikan dengan kondisi pendidikan di Indonesia. Nilai-nilai yang melekat pada sistem pendidikan akuntansi sekarang adalah sekularisme (paham yang membuat akuntansi terlepas dari nilai spiritualitas) dan paham liberal barat (Mulawarman, 2008). Sylvia (2014) menyatakan bahwa nilai-nilai pada era modernitas, seperti kapitalisme, materialisme, individualisme, dan sekularisme terbawa juga ke dalam akuntansi. Mulawarman (2012) berpendapat bahwa pendidikan akuntansi yang diajarkan dalam sistem pendidikan di Indonesia seharusnya sesuai dengan nilai-nilai dan jati diri bangsa, yaitu Pancasila.

Pendidikan dan pengajaran akuntansi yang dilakukan bertujuan untuk menyiapkan mahasiswa agar memiliki kemampuan dan kompetensi yang baik dalam bidang akuntansi. Diharapkan nantinya lulusan yang dihasilkan tidak hanya memiliki kemampuan teknis dan profesional yang baik, tetapi juga memiliki kepribadian dan karakter yang baik. Kepribadian dan karakter yang baik, misalnya bersikap profesional, jujur dalam melaksanakan tugas, cermat, dan memiliki rasa welas asih. Efferin (2015) berpendapat bahwa saat ini belum banyak kurikulum pendidikan tinggi akuntansi yang mencoba untuk memasukkan unsur spiritual dan kearifan lokal dalam setiap mata kuliah akuntansi. Dampaknya adalah praktek akuntansi hanya dipandang sebagai keterampilan teknis semata dan tidak memerlukan unsur-unsur nurani dalam pelaksanaan praktek akuntansi tersebut (Efferin, 2015). Molisa (2011) berpendapat bahwa penelitian mengenai pendidikan akuntansi dianggap kurang mendidik sehingga mengakibatkan banyak profesi akuntansi tidak mampu menyesuaikan diri dengan lingkungan bisnis yang terus berkembang. Boyce (2008) menjelaskan bahwa pemahaman akuntansi tidak cukup hanya dengan memasukkan nilai-nilai etis saja tetap juga harus dimasukkan dimensidimensi sosial, politik, etis dan lingkungan di mana isu-isu akuntansi itu berkembang. Jika pendidikan akuntansi hanya mengutamakan rasionalitas belaka tanpa 
mengandung unsur-unsur spiritual, maka lulusan akuntansi nantinya akan bercirikan rasionalitas, egois, apatis, tidak peka pada lingkungan sekitar, dan miskin nilai spiritualitas (Kamayanti, 2012).

Diperlukan teknik atau cara baru agar mahasiswa bisa lebih mudah memahami materi akuntansi yang telah bersifat internasional. Salah satu cara yang dapat dipergunakan adalah memberikan materi pendidikan dan pengajaran akuntansi dengan disertai unsur-unsur spiritual, unsur-unsur budaya, dan kearifan lokal (local wisdom) yang telah dipahami oleh mahasiswa. Saat ini belum banyak kurikulum pendidikan tinggi khususnya akuntansi yang secara khusus berusaha untuk memasukkan materimateri mengenai kearifan lokal dalam mata kuliah akuntansi (Efferin, 2015). Materi mengenai spiritualitas dan budi pekerti dianggap sebagai bagian yang tidak integral dalam materi akuntansi. Efferin (2015) berpendapat bahwa perlu adanya usaha untuk mendekatkan kearifan lokal (local wisdom) dengan akuntansi sehingga praktekpraktek akuntansi dapat berkembang dan memiliki manfaat untuk kesejahteraan sosial jangka panjang. Kearifan lokal mengandung nilai-nilai sosial dan budaya yang tidak hanya dapat meningkatkan kecerdasan peserta didik tetapi juga dapat meningkatkan nilai moralitas dan etika peserta didik. Akuntansi pada dasarnya membawa nilainilai etika, moral, spiritualitas namun nilainilai ini sering diabaikan karena kita terlalu mendewakan rasionalitas dan intelektualitas (Sylvia, 2014). Nilai-nilai karakter dan sosial harus dimasukkan ke dalam pendidikan agar peserta didik dapat menghayati dan memahami nilai-nilai moral kemanusiaan (Aufin, 2014).

Tulisan ini mencoba untuk memasukkan atau mensintesakan unsur-unsur spiritualitas, budaya, dan kearifan lokal, khususnya yang dimiliki oleh masyarakat Bali dalam materi kuliah akuntansi sosial dan lingkungan. Mata kuliah akuntansi sosial dan lingkungan dipilih untuk disintesakan dengan unsur- unsur spiritualitas, budaya, dan kearifan lokal dengan beberapa pertimbangan, yaitu (1) konsep akuntansi sosial dan lingkungan muncul sebagai jawaban atas tuntutan adanya kerusakan sosial dan lingkungan yang disebabkan oleh aktivitas bisnis perusahaan dan (2) materi-materi dalam mata kuliah akuntansi sosial dan lingkungan dapat dimasukkan unsur-unsur spiritualitas, budaya, dan kearifan lokal masyarakat Bali yang memang sebagian besar mengandung nilai-nilai sosial kemasyarakatan dan lingkungan. Diharapkan dengan lebih banyak memasukkan unsur-unsur spiritual, budaya, dan kearifan lokal akan membantu menghasilkan lulusan akuntansi yang tidak hanya memiliki keterampilan teknis yang baik, tetapi juga memiliki karakter dan kepribadian yang baik.

\section{Unsur Spiritualitas, Budaya, dan Kearifan Lokal dalam Pendidikan Akuntansi}

Sukarsa (2010) berpendapat bahwa konsep ekonomi selama ini hanya memasukkan manusia sebagai homo economicus yang menyatakan bahwa manusia harus menerapkan prinsip ekonomi dengan cara meminimalkan sumber daya untuk mendapatkan hasil yang maksimal. Akibat sifat ini maka akan muncul keserakahan dalam bisnis. Pelaku bisnis tidak hanya berpatokan pada laba yang akan didapat tetapi juga harus memikirkan dampak sosial dan dampak lingkungan dari kegiatan bisnis yang mereka lakukan. Memasukkan dimensi spiritualitas dalam bisnis bertujuan agar bisnis semakin bermanfaat bagi peradaban. Sukarsa (2010) mengedapankan istilah homospiritual bagi manusia dalam menjalankan bisnis yang mengedepankan nilai-nilai etika dalam berbisnis. Bisnis seringkali dijalankan dengan menghalalkan segala cara agar laba yang didapatkan perusahaan semakin besar (Ghani, 2006). Harus disadari bahwa pelaku dalam bisnis adalah manusia itu sendiri sehingga seringkali bisnis tersebut 
dijalankan dengan cara yang tidak baik (persaingan yang tidak sehat, ketidakjujuran, dan kecurangan).

Mulawarman dan Ludigdo (2010) berpendapat bahwa perilaku etis yang dimiliki oleh mahasiswa tidak cukup untuk mengantarkan mahasiswa menjadi akuntan yang profesional tetapi akuntansi harus dipahami sebagai ilmu dan nilai. Etika yang tinggi dalam menjalankan profesi akan membuat setiap orang yang terlibat dalam profesi akuntansi menjadi disegani. Secara tidak langsung hal ini akan membawa profesi akuntansi ke tingkat yang lebih terhormat. Sulistiyo (2012) berpendapat bahwa banyaknya skandal akuntansi dan manipulasi laporan keuangan serta rendahnya kepedulian perusahaan terhadap tanggung jawab sosial dan lingkungan menunjukkan bahwa telah terjadi perubahan dari sisi pelaku akuntansi. Dari pendapat Sulistiyo (2012) kita dapat menyimpulkan bahwa kecurangan-kecurangan yang terjadi dalam akuntansi lebih banyak disebabkan oleh pelaku akuntansi tersebut. Akuntansi sudah diciptakan sedemikian baiknya tetapi ketika yang menggunakan akuntansi tersebut hanya berdasar kepentingannya semata, maka akuntansi pun akan dipergunakan untuk kepentingan satu kelompok saja. Calon-calon pelaku akuntansi (mahasiswa) harus menyadari hal ini dan sudah seharusnya pendidikan akuntansi memberikan pemahaman bahwa etika dan moralitas sangat diperlukan dalam profesi akuntansi.

Mulawarman (2008) berpendapat bahwa tujuan dari pendidikan akuntansi adalah memberikan nilai "cinta yang melampaui" pada mahasiswa dalam bentuk keseimbangan antara akuntabilitas dan moralitas. Pada titik ini maka diharapkan lulusan akuntansi nantinya memiliki pertanggungjawaban moral tidak hanya kepada pemilik perusahaan atau investor saja, tetapi juga kepada masyarakat sosial dan lingkungan. Pada akhirnya orang-orang yang berkecimpung dalam profesi akuntansi tidak hanya bertanggung jawab secara hubungan bisnis kepada pihak tertentu, tetapi juga memiliki tanggung jawab moral kepada masyarakat dan lingkungan. Moralitas yang disertai dengan integrasi nilai-nilai spiritual akan dapat mencerahkan mahasiswa menuju cinta Allah (Mahabbatullah) (Mulawarman dan Ludigdo, 2010).

\section{Unsur Spiritualitas, Budaya, dan Kearifan Lokal Masyarakat Bali}

Unsur-unsur spiritualitas dalam masyarakat Bali sangat memperhatikan atau memfokuskan pada keadaan alam. Ini sangat sesuai dengan filosofi ketimuran yang mengagungkan alam karena telah memberikan berkah kepada manusia. Penghormatan-penghormatan kepada bagian alam sangat ditekankan pada nilai-nilai spiritual masyarakat Bali. Ini adalah bentuk sederhana dari unsur spiritualitas yang terdapat dalam masyarakat Bali. Kearifan lokal suatu daerah dapat berasal dari pengetahuan lokal (local knowledgement) yang dimiliki oleh masyarakat tersebut atau tradisi yang sudah berjalan lama di daerah tersebut. Karakteristik dari kearifan lokal adalah bahwa kearifan lokal tersebut harus mengajarkan mengenai nilai-nilai etika dan moral dan ajaran-ajaran kearifan lokal harus dapat mengajarkan untuk mencintai alam dan lingkungan. Masyarakat Bali juga memiliki beberapa konsep kearifan lokal yang sudah dianut selama ratusan tahun. Salah satu kearifan lokal yang dimiliki oleh masyarakat Bali, yaitu konsep tri hita karana, konsep manyama braya (hubungan kekeluargaan), konsep paras paros, dan konsep sagilig sagulug salunglung sabyantaka. Sebagian besar nilai-nilai dalam konsep kearifan lokal masyarakat Bali adalah nilai-nilai etika, sosial, dan kepedulian terhadap alam dan lingkungan.

Konsep tri hita karana merupakan sebuah konsep spiritual dan konsep kearifan lokal masyarakat Bali yang bertujuan untuk membentuk keselasaran hidup manusia. 
Kata tri hita karana berasal dari bahasa sanskerta yang terdiri dari tiga kata, yaitu "tri" yang berarti tiga, "hita" yang berarti kebaikan atau kemuliaan, dan "karana" yang berarti penyebab sehingga secara umum pengertian dari tri hita karana adalah tiga hal atau tiga penyebab yang mengakibatkan kehidupan manusia menjadi baik atau bahagia. Konsep tri hita karana terdiri dari konsep parahyangan (hubungan manusia dengan Tuhan (kata hyang berarti suci)), konsep pawongan (hubungan manusia dengan manusia (kata wong berarti manusia)), dan konsep palemahan (hubungan manusia dengan lingkungan atau alam). Ajaran utama dari konsep tri hita karana adalah bagaimana agar manusia mencapai keseimbangan dan keselarasan hidup. Menurut konsep tri hita karana, keseimbangan dan keselarasan hidup akan tercapai jika manusia menjalin hubungan yang baik dengan Tuhan, menjalin hubungan baik dengan sesama manusia, dan menjalin hubungan baik dengan lingkungan atau alam.

\section{METODE PENELITIAN}

Penelitian ini merupakan penelitian konseptual yang bertujuan untuk mensintesakan unsur-unsur spiritualitas, budaya, dan kearifan lokal dalam materi kuliah akuntansi sosial dan lingkungan. Pengumpulan data dalam penelitian ini selain ditentukan berdasarkan informasi pribadi yang dimiliki oleh penulis juga ditentukan berdasarkan dokumen-dokumen yang berisi mengenai materi pembelajaran mata kuliah akuntansi sosial dan lingkungan (silabus dan satuan acara perkuliahan) dan dosen yang mengampu mata kuliah tersebut. Observasi dilakukan untuk melihat bagaimana para pengajar menyampaikan materi kuliah akuntansi sosial dan lingkungan. Observasi juga dilakukan untuk melihat teknik atau cara pengajar

menyampaikan materi kuliah akuntansi sosial dan lingkungan dan materi-materi apa saja yang diajarkan dalam mata kuliah akuntansi sosial dan lingkungan tersebut. Proses wawancara dilakukan juga untuk mengetahui apakah para pengajar sudah memasukkan materi unsur-unsur spiritual, budaya, dan kearifan lokal dalam materi mata kuliah akuntansi sosial dan lingkungan. Wawancara juga dilakukan untuk mengetahui bagaimana respon pengajar mengenai proses pembelajaran akuntansi sosial dan lingkungan yang disertai dengan memasukkan unsur-unsur spiritual, budaya, dan kearifan lokal. Penelitian konseptual ini dilakukan di jurusan akuntansi program S1 Universitas Pendidikan Ganesha, Singaraja, Bali. Penelitian konseptual ini dilakukan di jurusan akuntansi program S1 Universitas Pendidikan Ganesha untuk mengetahui bagaimana proses pembelajaran akuntansi sosial dan lingkungan yang memasukkan unsur-unsur spiritual, budaya, dan kearifan lokal khas daerah Bali.

\section{HASIL PENELITIAN DAN PEMBA- HASAN}

Gambaran Umum Materi Kuliah Akuntansi Sosial dan Lingkungan pada Jurusan Akuntansi Program S1 Universitas Pendidikan Ganesha

Standar kompetensi dari mata kuliah ini adalah diharapkan mahasiswa memahami dan mampu mengaplikasikan konsep dasar akuntansi sosial dan lingkungan, konsep dasar corporate social responsibility dan dapat menjelaskan serta membuat komponen laporan keberlanjutan perusahaan dalam bentuk laporan keberlanjutan perusahaan. Sebaran materi yang disampaikan berikut ini merupakan materi yang terdapat dalam silabus mata kuliah akuntansi sosial dan lingkungan. Berikut adalah sebaran materi yang diajarkan pada setiap pertemuan: 


\begin{tabular}{|c|l|}
\hline $\begin{array}{c}\text { Pertemuan } \\
\text { Ke- }\end{array}$ & \multicolumn{1}{|c|}{ Materi Pokok } \\
\hline 1 & $\begin{array}{l}\text { Konsep dasar akuntansi sosial dan lingkungan dan sejarah munculnya } \\
\text { akuntansi sosial dan lingkungan }\end{array}$ \\
\hline 2 & $\begin{array}{l}\text { Konsep dasar, ruang lingkup, dan prinsip tanggung jawab sosial perusahaan/ } \\
\text { corporate social responsibility (CSR) }\end{array}$ \\
\hline 3 & $\begin{array}{l}\text { Konteks keberlanjutan dalam bisnis, green business, green economy, dan green } \\
\text { accounting }\end{array}$ \\
\hline 4 & $\begin{array}{l}\text { Rerangka pelaporan Global Reporting Initiative (GRI), prinsip-prinsip } \\
\text { pelaporan, dan standar pengungkapan }\end{array}$ \\
\hline 5 & Indikator kinerja ekonomi perusahaan \\
\hline 6 & Indikator kinerja sosial perusahaan \\
\hline 7 & Indikator kinerja lingkungan perusahaan \\
\hline 8 & Ujian tengah semester \\
\hline 9 & Konsep laporan berkelanjutan (sustainability report) \\
\hline 10 & Unsur-unsur laporan berkelanjutan pada industri manufaktur \\
\hline 11 & Unsur-unsur laporan berkelanjutan pada industri pertambangan \\
\hline 12 & Unsur-unsur laporan berkelanjutan pada industri perbankan \\
\hline 13 & Diskusi laporan berkelanjutan perusahaan pada industri manufaktur \\
\hline 14 & Diskusi laporan berkelanjutan perusahaan pada industri pertambangan \\
\hline 15 & Diskusi laporan berkelanjutan perusahaan pada industri perbankan \\
\hline 16 & Ujian akhir semester \\
\hline
\end{tabular}

Berdasarkan sebaran mata kuliah ini, kita dapat melihat bahwa secara garis besar materi mata kuliah akuntansi sosial dan lingkungan dibagi menjadi dua, yaitu pemahaman konsep dan aplikasi dari konsep. Pemahaman konsep ditekankan pada pertemuan 1 sampai 7 dan pertemuan 9 sampai 12. Aplikasi dari konsep ditekankan pada pertemuan 13 sampai 15. Metode pembelajaran yang dilakukan di kelas adalah metode presentasi dan diskusi. Setiap mahasiswa akan membentuk kelompok dan menyajikan materi yang didapat kelompok tersebut di depan kelas. Metode presentasi dilakukan saat membahas materi-materi kuliah yang berkaitan dengan konsep-konsep akuntansi sosial dan lingkungan. Metode diskusi dilakukan saat membahas materimateri aplikasi konsep, khususnya pada saat mahasiswa diminta untuk membuat laporan berkelanjutan perusahaan.

\section{Sintesa Unsur-Unsur Spiritualitas, Budaya, dan Kearifan Lokal dalam Konsep Dasar Mata Kuliah Akuntansi Sosial dan Lingkungan}

Jika materi konsep dasar akuntansi sosial dan lingkungan dikaitkan dengan unsurunsur spiritualitas, budaya, dan kearifan lokal maka akan sesuai dengan konsep kearifan lokal tri hita karana. Konsep kearifan lokal tri hita karana mengajarkan bahwa manusia harus mencapai keseimbangan secara spiritual (parahyangan), keseimbangan secara sosial (pawongan), dan keseimbangan dengan alam (palemahan). Konsep triple bottom lines juga secara tegas memberikan pemahaman bahwa perusahaan dalam menjalankan usahanya tidak hanya harus terfokus pada keuntungan semata (profit), tetapi juga harus memikirkan dampak dari usaha perusahaan pada lingkungan sosial (people) dan lingkungan alam di sekitar perusahaan (planet). Nuryaman (2013) berpendapat bahwa konsep people dalam kegiatan sosial perusahaan berarti bahwa 
entitas bisnis harus bertanggung jawab terhadap kesejahteraan sosial (social welfare) stakeholders perusahaan, konsep profit diartikan bahwa perusahaan tidak hanya mengejar keuntungan perusahaan semata tapi juga harus memberikan kemajuan kepada semua stakeholders perusahaan, dan konsep planet yang diartikan bahwa perusahaan harus bijak dalam mengelola sumber daya alam. Berdasarkan pemahaman ini maka sintesa konsep tri hita karana pada konsep akuntansi sosial dan lingkungan adalah unsur dalam triple bottom lines yang menyatakan bahwa perusahaan harus memikirkan juga lingkungan sosial (people) dan lingkungan alam (planet) dalam aktivitas perusahaan adalah sama dengan konsep bahwa manusia harus mencapai keseimbangan sosial (pawongan) dan keseimbangan dengan alam (palemahan) dalam konsep tri hita karana. Dengan sintesa konsep ini maka pemberian materi konsep akuntansi sosial dan lingkungan di kelas dapat ditekankan bahwa konsep triple bottom lines secara garis besar sama dengan konsep tri hita karana.

Unsur spiritual dari masyarakat Bali mengenal konsep catur purusa artha yang terdiri dari 4 bagian, yaitu dharma (kebaikan), artha (harta), kama (keinginan), dan moksha (kebebasan dari duniawi). Kata catur purusa artha berasal dari bahasa sanskerta yang memiliki arti, yaitu catur berarti empat, purusa berarti hidup, dan artha berarti tujuan. Secara keseluruhan catur purusa artha berarti empat tujuan hidup sebagai manusia. Tujuan hidup manusia sebagaimana dinyatakan dalam sebuah sloka "dharma, artha, kama, moksana sarira sadhanam" yang berarti bahwa badan yang disebut sarira hanya boleh dipergunakan sebagai alat untuk mencapai kebaikan, harta, keinginan, dan pembebasan duniawi. Dari konsep catur purusa artha ini kita dapat melihat bahwa Agama Hindu mengajarkan bahwa manusia dalam hidupnya harus memiliki tujuan sebagai manusia. Manusia harus bisa menggunakan kama (keinginan) untuk mendapatkan artha (tujuan hidup yang dalam konteks ini diartikan sebagai harta) dengan berlandaskan dharma (kebaikan) agar mendapatkan moksha (pembebasan dari kehidupan duniawi). Jika dilihat secara sepintas maka orang awam mungkin akan mengartikan bahwa tujuan hidup manusia sesuai ajaran Agama Hindu adalah mencari artha (harta). Konsep inti dari catur purusa artha mengajarkan bahwa manusia harus mencari artha bukan sebagai tujuan utama tetapi hanya sebagai sarana untuk mencapai tujuan yang sebenarnya. Tujuan yang sebenarnya dalam Agama Hindu adalah untuk mencapai moksha (jiwa manusia menyatu dengan jiwa Brahman (Tuhan)) dalam hal ini bahwa manusia sudah mencapai pembebasan yang sejati. Harta hanya sebagai sarana untuk menjalani hidup dan harta dapat pula dipergunakan untuk membantu orang lain. Jadi dalam pengertian yang sebenarnya tujuan hidup manusia bukanlah untuk mencari harta. Konsep inti berikutnya dari catur purusa artha adalah bahwa dalam mencari artha (harta) manusia harus berlandaskan dengan dharma (kebaikan). Manusia tidak diperbolehkan untuk menggunakan cara-cara yang tidak baik dalam mencari harta. Kebaikan harus menjadi dasar dalam segala perbuatan manusia dalam hidupnya. Jika kita sintesakan konsep catur purusa artha ini ke dalam konsep akuntansi sosial dan lingkungan maka dapat diartikan bahwa perusahaan dalam mencapai laba (profit atau artha) harus dilandasi dengan cara-cara yang baik (dharma). Perusahaan harus menyadari bahwa yang diuntungkan dari kegiatan perusahaan bukanlah hanya manajemen dan pemegang saham saja, tetapi semua stakeholder baik di internal maupun eksternal perusahaan juga harus dapat menikmati keuntungan yang didapatkan oleh perusahaan. Ini dapat diartikan bahwa tujuan perusahaan tidak hanya untuk menguntungkan manajemen dan pemegang 
saham tetapi unsur sosial dan lingkungan di sekitar perusahaan juga harus mendapatkan keuntungan. Perusahaan akan memberikan manfaat yang lebih luas kepada semua unsur baik yang ada di dalam maupun di luar perusahaan (moksha). Manajemen perusahaan tidak boleh menggunakan egonya (kama) hanya untuk kepentingan manajemen dan pemegang saham saja. Manajemen perusahaan harus menyadari bahwa banyak unsur sosial dan lingkungan yang telah membantu aktivitas perusahaan. Berdasarkan teori enterprise maka pada dasarnya income atau keberhasilan lain yang diperoleh perusahaan bukan hanya usaha dari manajemen perusahaan saja tetapi terdapat juga dukungan dari lingkungan sosial yang ada di luar perusahaan, misalnya dukungan dari pemerintah dan masyarakat (konsumen). Berdasarkan pemahaman ini maka dalam teori enterprise, lingkungan sosial lebih berkuasa dan lebih kuat dibandingkan dengan pemegang saham perusahaan (Soetedjo, 2009). Soetedjo (2009) dalam bukunya memberikan contoh perbandingan antara laporan laba rugi konvensional (tidak memasukkan nilai tambah kepada lingkungan sosial) dengan laporan laba rugi yang memasukkan faktor nilai tambah kepada lingkungan sosial dan lingkungan alam. Pada dasarnya konsep inipun sama dengan arti dari konsep triple bottom lines dimana perusahaan harus memikirkan faktor sosial dan lingkungan. Jika kita melihat pembahasan sintesa ini sebenarnya merupakan bukti bahwa nilai atau konsep dari akuntansi sosial dan lingkungan mengandung nilai-nilai universal yang dianut juga oleh ajaran agama dan berlaku dalam kehidupan manusia.

Gambaran Umum Materi Kuliah Akuntansi Sosial dan Lingkungan dengan Sintesa Unsur-Unsur Spiritualitas, Budaya, dan Kearifan Lokal

Tujuan dari penulisan artikel ini adalah untuk menemukan komposisi materi kuliah akuntansi sosial dan lingkungan yang disertai dengan sintesa unsur-unsur spiritualitas, budaya, dan kearifan lokal masyarakat Bali. Komposisi tersebut akan dibentuk dalam materi perkuliahan setiap pertemuan.

\begin{tabular}{|c|l|}
\hline $\begin{array}{c}\text { Pertemuan } \\
\text { Ke- }\end{array}$ & \multicolumn{1}{|c|}{ Materi Pokok } \\
\hline 1 & $\begin{array}{l}\text { Sejarah dan konsep dasar akuntansi sosial dan lingkungan dan hubungannya } \\
\text { dengan konsep spiritualitas catur purusa artha dan tri hita karana }\end{array}$ \\
\hline 2 & $\begin{array}{l}\text { Konsep, prinsip, dan ruang lingkup corporate social responsibility sebagai } \\
\text { perwujudan konsep tri hita karana dan manyama braya dalam bisnis }\end{array}$ \\
\hline 3 & $\begin{array}{l}\text { Konteks keberlanjutan dalam bisnis, green business, green economy, dan } \\
\text { green accounting : perwujudan konsep palemahan sebagai bagian dari } \\
\text { konsep tri hita karana }\end{array}$ \\
\hline 5 & $\begin{array}{l}\text { Rerangka pelaporan Global Reporting Initiative (GRI), prinsip-prinsip } \\
\text { pelaporan, dan standar pengungkapan }\end{array}$ \\
\hline 5 & $\begin{array}{l}\text { Indikator kinerja ekonomi perusahaan : tinjauan dari konsep spiritual catur } \\
\text { purusa artha }\end{array}$ \\
\hline 6 & $\begin{array}{l}\text { Indikator kinerja sosial perusahaan dan hubungannya dengan konsep kearifan } \\
\text { lokal manyama braya, paras paros, dan sagilig sagulug salunglung } \\
\text { sabyantaka }\end{array}$ \\
\hline 7 & $\begin{array}{l}\text { Indikator kinerja lingkungan, akuntansi air, konsep palemahan, dan filosofi } \\
\text { subak }\end{array}$ \\
\hline Ujian tengah semester \\
\hline
\end{tabular}




\begin{tabular}{|c|l|l|}
\hline 9 & $\begin{array}{l}\text { Konsep laporan berkelanjutan (sustainability report) sebagai bentuk } \\
\text { akuntabilitas informasi sosial dan lingkungan perusahaan }\end{array}$ \\
\hline 10 & $\begin{array}{l}\text { Unsur-unsur laporan berkelanjutan pada industri manufaktur dan } \\
\text { hubungannya dengan konsep spiritualitas, budaya, dan kearifan lokal } \\
\text { masyarakat Bali }\end{array}$ \\
\hline 11 & $\begin{array}{l}\text { Unsur-unsur laporan berkelanjutan pada industri pertambangan dan } \\
\text { hubungannya dengan konsep spiritualitas, budaya, dan kearifan lokal } \\
\text { masyarakat Bali }\end{array}$ \\
\hline 12 & $\begin{array}{l}\text { Unsur-unsur laporan berkelanjutan pada industri perbankan dan hubungannya } \\
\text { dengan konsep spiritualitas, budaya, dan kearifan lokal masyarakat Bali }\end{array}$ \\
\hline 13 & Diskusi laporan berkelanjutan perusahaan pada industri manufaktur \\
\hline 14 & Diskusi laporan berkelanjutan perusahaan pada industri pertambangan \\
\hline 15 & Diskusi laporan berkelanjutan perusahaan pada industri perbankan \\
\hline 16 & Ujian akhir semester \\
\hline
\end{tabular}

Pertemuan 1 membahas mengenai materi konsep akuntansi sosial dan lingkungan dan hubungannya dengan konsep tri hita karana dan catur purusa artha. Pertemuan 2 membahas mengenai konsep tanggung jawab sosial dan dihubungkan dengan konsep tri hita karana dan manyama braya. Pengajar dapat memberikan materi bagaimana tanggung jawab sosial dan lingkungan perusahaan ditinjau dari ruang lingkup tri hita karana dan manyama braya. Pertemuan 3 membahas konsep keberlanjutan dalam bisnis dan konsep turunan dalam akuntansi sosial dan lingkungan. Dalam materi ini mahasiswa diharapkan dapat memahami bahwa pada dasarnya konsep-konsep akuntansi sosial dan lingkungan sesuai dengan nilai-nilai budaya dan kearifan lokal yang selama ini berkembang di daerah asal. Pertemuan 4 membahas mengenai rerangka pelaporan, prinsip, dan standar dalam pengungkapan informasi sosial dan lingkungan. Materi ini tidak dihubungkan dengan konsep spiritualitas, budaya, dan kearifan lokal karena yang dibahas adalah standar pengungkapan yang masih bersifat internasional. Pertemuan 5 membahas mengenai aspek kinerja ekonomi perusahaan ditinjau dari konsep catur purusa artha. Pada materi ini mahasiswa diharapkan dapat memahami bahwa perusahaan dalam mencari laba harus juga melihat aspek sosial dan lingkungan di luar perusahaan. Pertemuan 6 diisi dengan membahas itemitem kinerja sosial pada standar GRI dan dihubungkan dengan konsep kearifan lokal sosial masyarakat Bali. Pada pertemuan 7 dibahas mengenai kinerja lingkungan perusahaan. Pada pertemuan ini mahasiswa dikenalkan dengan konsep akuntansi air dan hubungannya dengan konsep palemahan. Pertemuan ini dapat juga membahas nilainilai budaya dalam sistem subak dan dihubungkan dengan kinerja lingkungan perusahaan. Pertemuan 9 membahas mengenai laporan berkelanjutan perusahaan sebagai bentuk transparansi dan akuntabilitas informasi ekonomi, sosial, dan lingkungan yang dimiliki oleh perusahaan. Pertemuan 10 sampai 12 diisi dengan pembahasan unsur-unsur laporan berkelanjutan perusahaan dari berbagai industri dan item-item dalam laporan berkelanjutan itu dapat dihubungan dengan nilai-nilai spiritualitas, budaya, dan kearifan lokal masyarakat Bali. Pertemuan 13 sampai 15 dilakukan dengan mahasiswa diminta menyusun laporan berkelanjutan perusahaan yang berisi aspek kinerja ekonomi, kinerja sosial, dan kinerja lingkungan yang sesuai dengan standar GRI dan harus berisi nilainilai atau konsep spiritual, budaya, dan kearifan lokal yang dipahami oleh mahasiswa. 
Kurikulum pendidikan tinggi di Indonesia disusun berdasarkan KKNI (kerangka kualifikasi nasional Indonesia) yang merupakan penjenjangan kompetensi yang harus dimiliki oleh lulusan perguruan tinggi. KKNI disusun agar sistem pendidikan dapat menghasilkan lulusan yang nantinya sesuai dengan yang dibutuhkan oleh dunia kerja. Penyusunan kurikulum yang didasarkan pada KKNI harus mencerminkan nilai-nilai yang dimiliki oleh bangsa Indonesia, namun tetap dengan visi dan misi yang berwawasan global. Lulusan pendidikan tinggi akuntansi harus berprinsip seperti "pohon beringin", dimana cabangnya menjulang ke atas (visi dan misinya berwawasan global dan mampu bersaing di dunia internasional) dan akarnya tertancap kuat ke bumi (memiliki nilai-nilai spiritualitas, budaya, dan kearifan lokal sesuai jati diri bangsanya). Lulusan pendidikan tinggi akuntansi harus menjunjung dharma (kebenaran) dalam menjalankan tugasnya nanti dan dapat bertindak berdasarkan konsep spiritualitas tri kaya parisudha (berpikir yang baik, berkata yang baik, dan berbuat yang baik).

\section{SIMPULAN DAN SARAN}

Sintesa unsur budaya, spiritualitas, dan kearifan lokal dalam pendidikan akuntansi bermaksud agar akuntansi lebih "membumi" dan mudah dipahami. Akuntansi yang lebih "membumi" akan membuat tujuan akuntansi tercapai. Kita harus menyadari bahwa akuntansi adalah alat yang dapat dipergunakan untuk mencapai kesejahteraan sosial (social welfare) atau kebahagiaan yang sebenarnya (mokshartam jagadhita). Akuntansi tidaklah hanya akuntansi itu sendiri tetapi di dalamnya terdapat nilai politik, sosial, budaya, dan unsur lain yang dapat membentuk akuntansi itu seutuhnya. Nilai laba dalam akuntansi tidak hanya akan dimaknai untuk kepentingan manajemen dan pemegang saham saja, tetapi laba dapat dimaknai untuk kepentingan semua stakeholder perusahaan. Cinta yang terdapat dalam unsur-unsur akuntansi akan membuat akuntansi memiliki perhatian yang lebih kepada semua stakeholder sehingga tidak lagi menjadi akuntansi yang materialistis (Sylvia, 2014). Akuntansi yang berkembang di Indonesia harus menghasilkan "anak-anak akuntan" yang beretika, bernilai kebaikan, membela rakyatnya, dan tetap berwajah asli Indonesia (Kusdewanti et al., 2014).

Keterbatasan dalam penelitian ini adalah bahwa penelitian ini bersifat konseptual dan belum pernah diaplikasikan dalam pembelajaran di kelas. Penulis menyarankan agar sintesa unsur-unsur spiritualitas, budaya, dan kearifan lokal ini benar-benar dapat diaplikasikan dalam proses perkuliahan. Dengan kata lain materi mengenai unsur-unsur spiritualitas, budaya, dan kearifan lokal dapat dimasukkan sebagai bagian dari silabus dan satuan acara perkuliahan. Tujuan akhir dari kegiatan ini dan kegiatan belajar mengajar pada umumnya adalah membentuk lulusan pendidikan tinggi akuntansi yang berkompeten dan berkarakter. Orang-orang yang nantinya akan berkecimpung dalam profesi akuntansi selain harus memiliki kompetensi yang baik juga harus memiliki nilai spiritualitas yang tinggi, moralitas yang baik, dan karakter yang baik sehingga tujuan utama dari akuntansi akan dapat tercapai.

\section{DAFTAR PUSTAKA}

Aufin, M. (2014). "Sintesa Pendidikan Karakter dan Multikultural bagi Lingkungan Pendidikan Tinggi." Jurnal Psikologi. Volume II Nomor 2. Hal 110-125

Boyce, G. (2008). "The Social Relevance of Ethics Education in a Global(ising) Era: From Individual Dilemmas to Systemic Crises." Critical Perspectives on Accounting. Volume 19. Hal 255-290

Efferin, Sujoko. (2015). Prospek Penelitian Kritis Akuntansi Berbasis Local 
Wisdom: Belajar dari Tri Hita Karana dan Udayana. Disajikan dalam Pertemuan Masyarakat Akuntansi Multiparadigma Indonesia (TEMAN 3), Universitas Udayana, Denpasar, 26-27 Maret 2015

Ghani, M.A. (2006). The Spirituality in Business - Pencerahan Hati Bagi Pelaku Usaha. Jakarta: Penerbit Pena

Kamayanti, A. (2012). Developing Conscious Accounting Educators: A Theatrical Perspective. Tesis tidak Dipublikasikan. Universitas Brawijaya, Malang

Kusdewanti, A.I., A.R. Setiawan, A. Kamayanti, \& A. D. Mulawarman. (2014). "Akuntansi Bantengan: Perlawanan Akuntansi Indonesia Melalui Metafora Bantengan dan Topeng Malang." Jurnal Akuntansi Multiparadigma. Volume 5 Nomor 1. Hal 149-169

Molisa, P. (2011). "A Spiritual Reflection on Emancipation an Accounting." Critical Perspectives on Accounting. Volume 22. Hal 453-484

Mulawarman, A. D. (2008). "Pendidikan Akuntansi Berbasis Cinta: Lepas dari Hegemoni Korporasi Menuju Pendidikan yang Memberdayakan dan Konsepsi Belajar yang Melampaui." Jurnal EKUITAS. Volume 12 Nomor 2. Hal $142-158$

Mulawarman, A. D. (2012). Menggugat Pendidikan Akuntansi Indonesia: Pro Neoliberal atau Pancasila? Disajikan

$\begin{array}{lcr}\begin{array}{l}\text { dalam } \\ \text { Pendidikan }\end{array} & \text { Konferensi } & \text { Akuntansi } \\ \text { Malang, 18-20 April 2012 } & \text { Indonesia, }\end{array}$

Mulawarman, A. D. \& U. Ludigdo. (2010). Metamorfosis Kesadaran Etis Holistik Mahasiswa Akuntansi (Implementasi Pembelajaran Etika Bisnis dan Profesi Berbasis Integrasi IESQ). Simposium Nasional Akuntansi XIII Purwekerto.

Nuryaman. (2013). The Effect of Corporate Social Responsibility Activities on Profitability and Stock Price (Studies on The Companies Listed on Indonesia Stock Exchange). $4^{\text {th }}$ International Conference on Business and Economic Research $\left(4^{\text {th }}\right.$ ICBER 2013) Proceeding: 756-769

Soetedjo, S. (2009). Pembahasan PokokPokok Pikiran Teori Akuntansi Vernon Kam. Surabaya: Airlangga University Press

Sukarsa, (2010). Spiritual Economics dalam Era Globalisasi Ekonomi. Disajikan dalam Seminar Regional : Ekonomi Berbasis Kearifan Lokal, Universitas Udayana, 11 Juni 2010

Sulistiyo, A.B. (2012). "Antara Seni Berperang Ala Sun Tzu, Akuntansi, dan Sustainabilitas Organisasi." Ekuitas: Jurnal Ekonomi dan Keuangan. Volume 16 Nomor 1. Hal 16-31

Sylvia. (2014). "Membawakan Cinta Untuk Akuntansi." Jurnal Akuntansi Multiparadigma. Volume 5 Nomor 1. Hal 139-148 